\title{
SUMO-Activating Enzyme Subunit 1
}

National Cancer Institute

\section{Source}

National Cancer Institute. SUMO-Activating Enzyme Subunit 1. NCI Thesaurus. Code C101573.

SUMO-activating enzyme subunit 1 (346 aa, $\sim 38 \mathrm{kDa}$ ) is encoded by the human SAE1 gene. This protein is involved in the regulation of sumoylation. 